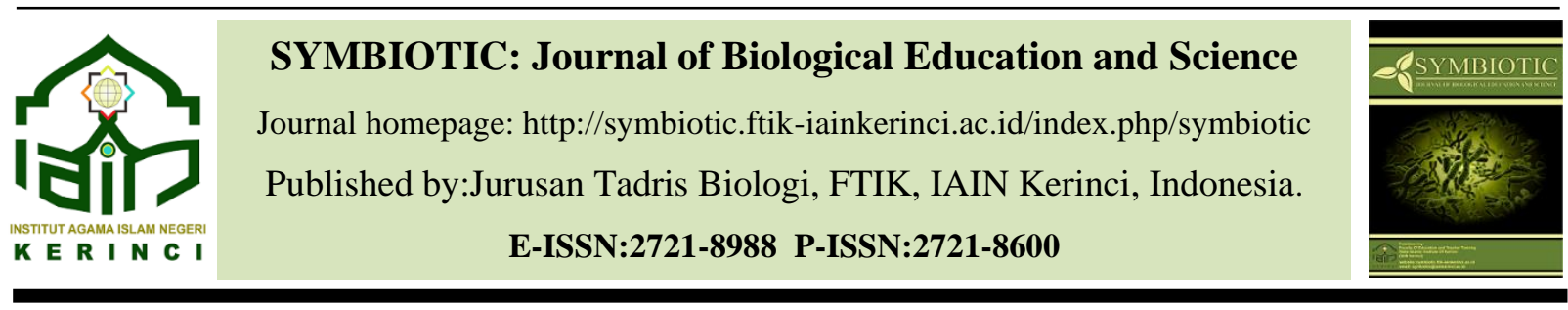

\title{
Pengaruh Model Pembelajaran Sains Teknologi Masyarakat (STM) Terhadap Kemampuan BerPikir Kreatif Dan Self Regulation
}

\author{
Aulia Novitasari $^{1}$, Agus Jatmiko ${ }^{1}$, Fahmi Elen ${ }^{1}$ \\ ${ }^{1}$ Pendidikan Biologi, Fakultas Tarbiyah Dan Keguruan, \\ Universitas Islam Raden Intan Lampung \\ Jl. H. Suratmin Sukarame Bandar Lampung 35131 \\ e-mail korespondensi: aulianovitasari@radenintan.ac.id
}

\begin{abstract}
The ability to think creatively is a 21 st century learning ability that students must have, this ability is needed to find new ideas that can be used to solve problems in the real world, the process of finding ideas is closely related to self regulation. The Community Technology Science Model is a learning model that aims to prepare students to practice the value of science, apply scientific knowledge and solve problems in the community, with ideas that are happening in society as topics in learning, this model is expected to improve creative thinking skills and self-regulation. . This study aims to determine the effect of the Science Technology Society model on creative thinking skills and self regulation. This type of research is quantitative with the Quasi Experiment method, the research design is Posttest-Only Control Group Design. The population in this study were all class VIII SMPN 1 Sumberejo, the sample was obtained using cluster random sampling, namely class VIII A as the experimental class and VIII B as the control class. Based on data analysis using MANOVA, the results obtained were sig $<0.05$, which means that the Science Technology Community learning model has an effect on creative thinking skills and self-regulation of students of class VIII SMPN 1 Sumberejo.
\end{abstract}

Keyword : Science Technology Society, Creative Thinking Skills, Self Regulation.

\begin{abstract}
ABSTRAK
Kemampuan berpikir kreatif merupakan kemampuan pembelajaran abad 21 yang harus dimiliki peserta didik, kemampuan ini diperlukan untuk menemukan ide - ide baru yang dapat digunakan untuk memecahkan masalah dalam dunia nyata, proses penemuan ide-ide berkaitan erat dengan self regulation. Model Sains Teknologi Masyarakat adalah model pembelajaran yang bertujuan untuk mempersiapkan siswa untuk mengamalkan nilai sains, menerapkan pengetahuan ilmiah dan memecahkan masalah di lingkungan masyarakat, dengan ide yang tengah terjadi di masyarakat sebagai topik dalam pembelajaran, model ini diharapkan dapat meningkatkan kemampuan berpikir kreatif dan self regulation. Penelitian ini bertujuan untuk melihat pengaruh model Sains Teknologi Masyarakat terhadap kemampuan berpikir kreatif dan self regulation. Jenis penelitian ini adalah kuantitatif dengan metode Quasi Eksperimen, desain penelitian Posttest-Only Control Group Design. Populasi dalam penelitian ini adalah seluruh kelas VIII SMPN 1 Sumberejo, diperoleh sampel dengan cluster random sampling yaitu kelas VIII A sebagai kelas eksperimen dan VIII B sebagai kelas kontrol. Berdasarkan analisis data menggunakan MANOVA, diperoleh hasil sig<0,05 artinya model pebelajaran Sains Teknologi Masyarakat berpengaruh terhadap kemampuan berpikir kreatif dan self regulation peserta didik kelas VIII SMPN 1 Sumberejo
\end{abstract}

Kata Kunci :Sains Teknologi Masyarakat,Kemampuan Berpikir Kreatif, Self Regulation. 


\section{PENDAHULUAN}

Abad ke-21 merupakan era revolusi industry 4.0 sebagai babak baru perubahan kehidupan manusia yang fundamental, menuntut hasil usaha dan sumberdaya manusia yang berkualitas, memunculkan gagasan dan terobosan baru, professional yang mengikuti kemajuan ilmu pengetahuan dan teknologi, memiliki tindakan dan cara berpikir yang rasional, salah satunya adalah berpikir kreatif (Nugroho, R. dkk, 2018; Dedi, 2019; Sastria dkk, 2020). Kemampuan berpikir kreatif merupakan kemampuan yang sangat penting dalam era persaingan yang sangat tinggi permasalahan dalam kehidupan di masyarakat, karena seseorang yang memiliki kemampuan berpikir kreatif mampu menggali ide - ide baru yang berakibat pada berkembangnya kemampuan skill dan pengetahuan yang berguna untuk pemecahan masalah dalam kehidupan serta menemukan hal-hal dan inovasi baru dalam hidupnya (Rina, P, dkk, 2017)

Kemampuan berpikir kreatif berpengaruh terhadap pembelajaran sains. Ilmu sains ini tidak hanya menggali pengetahun secara deklaratif yaitu berupa konsep, fakta, pedoman dan pemahaman, wawasan yang terarah serta cara mendapatkan informasi sains dan teknologi yang digunakan bekerja,tetapi membiasakan bekerja secara ilmiah serta terampil dalam pola pemikiran. Aktivitas pembelajaran yang memikirkan pentingnya berpikir kreatif akan berdampak pada terciptanya sebuah pemikiran, gagasan maupun karya yang baru. Kemampuan berpikir kreatif memungkinkan peserta didik untuk melihat masalah dari perspekif dan pemecahan masalah yang berbeda, sehingga mampu meraih kesempatan yang lebih besar untuk menyelesaikan masalah dan memperoleh penghargaan, oleh karena itu kemampuan berpikir kreatif penting dimiliki oleh peserta didik ( Budhi, Y. 2016; Hasanah, 2019). namun kenyataan di lapanngan bahwa kemampuan berpikir kreatif kurang terlatihkan. Berdasarkan hasil prapenelitian yang dilakukan dengan membagikan soal dengan indikator berpikir kreatif di SMP $\mathrm{N} 1$ Sumberjo diperoleh hasil bahwa kemampuan peserta didik masih rendah yaitu:

Tabel 1. Hasil Prapenelitian Kemampuan Berpikir Kreatif

\begin{tabular}{ccccc}
\hline No & Indikator & Skor & Pencapaian & Kriteria \\
\hline 1 & Berpikir Lancar & 3 & $41,1 \%$ & Rendah \\
\hline 2 & Berpikir Luwes & 3 & $39,4 \%$ & Rendah \\
\hline 3 & Berpikir Orisini & 3 & $39,8 \%$ & Rendah \\
\hline 4 & Berpikir Elaborasi & 3 & $36,1 \%$ & Rendah \\
\hline
\end{tabular}

Keberhasilan peserta didik dalam mencapai tujuan pembelajaran tidak hanya dipengaruhi oleh aspek berpikirnya, tetapi keberhasilan peserta didik juga dipengaruhi oleh aspek psikologis. Aspek psikologis tersebut adalah Self regulation. Self regulation adalah konsep mengenai bagaimana cara seorang peserta didik mengatur dirinya sendiri selama proses belajar, kemampuan untuk merencanakan, mengembangkan, dan mengimplementasikan ide/ gagasan baru, sehingga pengaturan diri peserta didik 
erat kaitannya dengan kemampuan berpikir kreatif, dengan kata lain kemampuan berpikir kreatif yang tinggi dipengaruhi oleh self regulation yang baik sedangkan kemampuan berpikir kreatif yang rendah dipengaruhi oleh self regulation yang kurang baik (Tatang, Y.E.S, 2016). Hal ini sesuai dengan hasil prapenelitian yang dilakukan dengan menyebarkan angket self regulation meliputi indikator sadar akan sebuah pemikiran sendiri, membuat sebuah perencanaan secara efektif, sadar dan menggunakan sumber-sumber informasi yang dibutuhkan serta Sensitif dengan adanya umpan balik, yang menunjukkan kriteria rendah yaitu:

Tabel 2. Hasil Prapenelitian Self Regulation

\begin{tabular}{clccc}
\hline No & \multicolumn{1}{c}{ Indikator } & Skor & Pencapaian & Kriteria \\
\hline 1 & Menyadari pemikiran sendiri & 4 & $39,9 \%$ & Rendah \\
\hline 2 & Membuat rencana secara efektif & 4 & $35,9 \%$ & Rendah \\
\hline 3 & $\begin{array}{l}\text { Sadar dan menggunakan sumber- } \\
\text { sumber informasi yang di } \\
\text { butuhkan }\end{array}$ & 4 & $37,9 \%$ & Rendah \\
\hline 4 & Sensitive terhadap umpan balik & 4 & $35,9 \%$ & Rendah \\
\hline
\end{tabular}

Pada dasarnya kemampuan berpikir kreatif dapat dilatihkan agar dapat berkembang dengan baik. Kemampuan berpikir kreatif bukanlah bakat alami yang hanya ada pada sebagian orang saja, tetapi setiap orang dapat memilikinya dengan berlatih dan mengasahnya, begitu juga denngan self regulation. Berdasarkan hasil prapenelitian pada kedua aspek yang tertera pada tabel diatas menunjukkan bahwa kemampuan berpikir kreatif dan self regulation kurang terlatihkan, hal ini didukung berdasarkan hasil observasi dan wawancara diperoleh data bahwa metode yang digunakan guru adalah metode ceramah, metode ini membuat peserta didik pasif hanya mendengarkan penjelasan dari guru, yang berakibat pada hasil belajar yang cenderung memindahkan jawaban dari buku. Peserta didik kurang terasah kemampuan dalam mengeluarkan ide atau pendapat untuk memecahkan masalah, sulit mengaitkan permasalahan dunia nyata dengan pembelajaran yang berdampak pada rendahnya kemampuan berpikir kreatif, solusi untuk mengatasi permasalahan tersebut dibutuhkan model pembelajaran yang dapat merangsang siswa mengeluarkan ide atau gagasan dan mengaitkan pembelajaran dengan dunia nyata yaitu model Sains Teknologi Masyarakat. (Ayu, M. A.,dkk, 2017; Purwakarti, 2016).

Model pembelajaran Sains Teknologi Masyarakat merupakan salah satu model yang memberikan pengalaman langsung bagi peserta didik, karena pembelajarannya dikemas dengan memunculkan isu atau masalah yang tengah terjadi di masyarakat sebagai topik dalam pembelajaran, (Widodo, A., dkk, 2007) sehingga siswa dapat merasakan pembelajaran yang bermakna, karena di dalam pembelajarannya siswa didorong untuk menggunakan kemampuan berpikirnya untuk mencari solusi permasalahan yang tengah terjadi di masyarakat, sehingga peserta didik berpikir menggunakan konsep - konsep sains yang diperolehnya untuk mengatasi permasalahan, selain itu model pembelajaran STM menekankan cara belajar yang aktif yang baik yang mencakup ranah kognitif, afektif, dan 
psikomotorik yang berdampak pada perbaikan pengaturan diri peserta didik (Anna, P, 2007) Adapun rumusan masalah dalam penelitian ini adalah apakah terdapat pengaruh model pembelajaran sains teknologi masyarakat terhadap kemampuan berpikir kreatif dan self regulation.

\section{METODE}

Penelitian dilakukan pada semester genap tahun pelajaran 2019/2010.Tempat penelitian di SMP N 1 Sumberejo dan subjek pada penelitian ini yaitu peserta didik kelas VIII SMP N 1 Sumberejo.Dalam penelitian ini peneliti menggunakan teknik acak kelas di mana kelompok penelitian kelas VIII A sebagai kelas eksperimen dengan jumlah siswa 28 dan kelas VIII B sebagai kelas kontrol dengan jumlah siswa 27. Pada penelitian ini memakai instrument dalam lembaran soal tes yang disajikan berbentuk essay yang nanti digunakan untuk menimbang hasil kemampuan berpikir kreatif, soal yang akan diberikan kepada siswa adalah materi zat aditif dan adiktif serta angket guna mengukur Self regulation yang dimiliki siswa (Darmiyati, Z, 2010).

Instrumen yang diuji cobakan dalam penelitian merupakan soal postest yang berupa essay dan selanjutnya dilakukan uji validitas, reliabilitas, daya pembeda, dan tingkat kesukaran. Sedangkan, angket yang digunakan dijadikan sebagai data peninjau Self Regulation peserta didik.Untuk menguji hipotesis dapat digunakan Manova dengan menggunakan aplikasi SPSS versi 16 (Sugiono,2017; Martono, 2015).

\section{HASIL DAN PEMBAHASAN}

\section{Hasil Pengamatan}

Data hasil kemampuan berpikir kreatif diperoleh dari hasil tesdenganjenis soal essay, sedangkan data self regulation diperoleh dari angket dengan indikator meliputi sadar akan sebuah pemikiran sendiri, membuat sebuah perencanaan secara efektif, sadar dan menggunakan sumber-sumber informasi yang dibutuhkan serta sensitif dengan adanya umpan balik.Populasi dalam penelitian ini adalah kelas VIII dengan teknikpengambilan sample cluster random sampling dan didapatkan hasil kelas VIII b yang berjumlah 27 peserta didik dan kelas VIII c yang berjumlah 30 peserta didik. Pembelajaran kelas eksperimen menggunakan model sains teknologi masyarakat, sedangkan pada kelas kontrol menggunakan model direct instruction. Data hasil penelitian dijabarkan pada tabel berikut:

Tabel 3. Hasil Postest Berpikir Kreatif Kelas Eksperimen Dan Kelas Kontrol

\begin{tabular}{cccc}
\hline \multirow{2}{*}{ No } & \multirow{2}{*}{ Kriteria } & Ekperimen & Hasil \\
& Nilai maksimum & 93 & Kontrol \\
\hline 1 & Nilai minimum & 52 & 81 \\
\hline 2 & Jumlah & 1959 & 33 \\
\hline 3 & Rata-rata & 72,80 & 1968 \\
\hline 4 & & & 65,6 \\
\hline
\end{tabular}


Adapun persentase capaian dari setiap indikator kemampuan berpikir kreatif setelah diberi perlakuan model sains teknologi masyarakat adalah sebagai berikut.

Tabel 4. Hasil Perindikator Kemampuan Berpikir Kreatif Kelas Eksperimen

\begin{tabular}{ccccc}
\hline No & Indikator & Nomor soal & Persentase & Keterangan \\
\hline 1 & Berpikir luwes & $1,2,9$ & $76 \%$ & Tinggi \\
\hline 2 & Berpikir lancar & 2,4 & $76 \%$ & Tinggi \\
\hline 3 & Berpikir orisisnil & $5,6,7$ & $67 \%$ & Sedang \\
\hline 4 & Berpikir elaborasi & 8 & $77 \%$ & Tinggi \\
\hline
\end{tabular}

Tabel 5. Hasil Perindikator Kemampuan Berpikir Kreatif Kelas Kontrol

\begin{tabular}{ccccc}
\hline No & Indikator & Nomor Soal & Persentase & Keterangan \\
\hline 1 & Berpikir Luwes & $1,2,9$ & $67 \%$ & Tinggi \\
\hline 2 & Berpikir Lancar & 2,4 & $71 \%$ & Tinggi \\
\hline 3 & Berpikir Orisinil & $5,6,7$ & $62 \%$ & Sedang \\
\hline 4 & Berpikir Elaborasi & 8 & $66 \%$ & Tinggi \\
\hline
\end{tabular}

Tabel 6. Hasil Perindikator Self Regulation Kelas Eksperimen

\begin{tabular}{clccc}
\hline No & \multicolumn{1}{c}{ Indikator } & Nomor Soal & Persentase & Keterangan \\
\hline 1 & $\begin{array}{l}\text { Sadar akan sebuah } \\
\text { pimikiran sendiri. }\end{array}$ & $1,2,3,4,5,6$ & $82,00 \%$ & Baik \\
\hline 2 & $\begin{array}{l}\text { Membuat sebuah } \\
\text { perencanaan secara efektif } \\
\text { planning) }\end{array}$ & $\begin{array}{c}7,8,9,10,11,1 \\
2\end{array}$ & $84,20 \%$ & Baik \\
\hline \multirow{2}{*}{3} & $\begin{array}{l}\text { Sadar dan menggunakan } \\
\text { sumber informasi yang } \\
\text { dibutuhkan }\end{array}$ & $\begin{array}{c}13,14,15,16, \\
17,18\end{array}$ & $78,00 \%$ & Baik \\
\hline 4 & $\begin{array}{l}\text { Sensitive dengan adanya } \\
\text { umpan balik. }\end{array}$ & $\begin{array}{c}19,20,21,22, \\
23,24,25\end{array}$ & $86,00 \%$ & Sangat Baik \\
\hline
\end{tabular}

Tabel 7. Hasil Perindikator Self Regulation Kelas Kontrol

\begin{tabular}{|c|c|c|c|c|c|}
\hline No & Indikator & Indikator & $\begin{array}{c}\text { Nomor } \\
\text { Soal }\end{array}$ & Persentase & Keterangan \\
\hline 1 & $\begin{array}{l}\text { Sadar akan } \\
\text { sebuah } \\
\text { pimikiran } \\
\text { sendiri. }\end{array}$ & $\begin{array}{l}\text { Menyiapkan } \\
\text { ruang lingkup } \\
\text { pembelajaran. }\end{array}$ & $\begin{array}{c}1,2,3,4,5 \\
6\end{array}$ & $76,00 \%$ & Baik \\
\hline 2 & $\begin{array}{l}\text { Membuat } \\
\text { sebuah } \\
\text { perencanaan } \\
\text { secara efektif } \\
\text { (planning) }\end{array}$ & $\begin{array}{l}\text { Mengatur } \\
\text { bahan ajar }\end{array}$ & $\begin{array}{c}7,8,9,10 \\
11,12\end{array}$ & $74,00 \%$ & Cukup \\
\hline 3 & $\begin{array}{l}\text { Sadar dan } \\
\text { menggunakan } \\
\text { sumber } \\
\text { informasi yang } \\
\text { dibutuhkan }\end{array}$ & $\begin{array}{l}\text { Mengontrol } \\
\text { perkembangan } \\
\text { diri }\end{array}$ & $\begin{array}{c}13,14,15 \\
16,17,18\end{array}$ & $70,00 \%$ & cukup \\
\hline
\end{tabular}




\begin{tabular}{lllcc}
\hline Sensitive & Melakukan & 19,20,21, & & \\
dengan adanya & evaluasi & 22,23,24, & $77,00 \%$ & Baik \\
umpan balik. & terhadap hasil & 25 & & \\
& kinerja. & & \\
\hline
\end{tabular}

Penelitian ini dilaksanakan di SMPN 1 Sumberejo dengan populasi seluruh peserta didik kelas VIII, teknik pengambilan sampel yaitu cluster random sampling diperoleh kelas VIII B sebagai kelas eksperimen dan kelas VIII A sebagai kelas kontrol. Variabel terikat pada penelitian ini adalah kemampuan berpikir kreatif dan self regulation, sedangkan variabel bebas pada penelitian ini adalah model pembelajaran Sains Teknologi Masyarakat. Instrument tes untuk mengukur kemampuan berpikir kreatif adalah soal essay yang sebelumnya di uji kelayakannya menggunakan expert judgment, sedangkan untuk mengukur self regulation menggunakan angket dengan indikator sadar akan sebuah pemikiran sendiri, membuat sebuah perencanaan secara efektif, sadar dan menggunakan sumbersumber informasi yang dibutuhkan serta Sensitif dengan adanya umpan balik. (Frangkel, R \& Wallen, E.N, 2017).

Data hasil analisis multivariat diperoleh hasil bahwa terdapat pengaruh model pembelajaran Sains Teknologi Masyarakat terhadap kemampuan berpikir kreatif dan self regulation peserta didik kelas VIII SMP N 1 Sumberejo. Data hasil tes univariat terhadap masing-masing variabel terikat diperoleh hasil terdapat pengaruh model pembelajaran Sains Teknologi Masyarakat terhadap kemampuan berpikir kreatif, dengan taraf signifikansi $<0,05$, hal ini sejalan dengan hasil penelitian terdahulu yang dilakukan oleh Smarabawa (2019) yaitu kemampuan berpikir kreatif peserta didik yang menggunakan model Sains Teknologi Masyarakat dengan pendekatan saintifik memberikan hasil yang lebih baik dibandingkan dengan kelas yang menggunakan model konvensional. Penelitian selanjutnya oleh N.W. Heni Desianti (2017) menyatakan bahwa model pembelajaran Sains Teknologi Masyarakat sangat efektif untuk meningkatkan kemampuan berpikir kreatif peserta didik sebelun menggunakan model pembelajaran Sains Teknologi Masyarakat. Hasil uji terhadap variabel kedua yaitu self regulation diperoleh hasil terdapat pengaruh model pembelajaran Sains Teknologi Masyarakat terhadap self regulation, dengan taraf signifikansi < 0,05 yang artinya $\mathrm{H} 1$ diterima.

Hasil yang signifikan terhadap kedua variabel dikarenakan pada saat proses pembelajaran berlangsung siswa berperan aktif dalam kegiatan pembelajaran mengaitkan materi dengan dunia nyata sehingga mmpu memunculkan ide -ide atau gagasan baru., selain itu model pembelajaran Sains teknologi Masyarakat mampu menunjang pengembangan kemampuan berpikir kreatif pada saat proses diskusi berlangsung, peserta didik dibimbing dalam berdiskusi secara berkelompok untuk memahami materi yang disampaikan. Cara seperti ini akan mendorong peserta didik menggali pengetahuan dan menghubungkan konsep pengetahuan awal dengan konsep yang baru diterima. Model Pembelajaran Sains teknologi Masyarakat merupakan model pembelajaran yang konstruktivistik, pembelajaran yang menekankan aspek kerjasama antar peserta didik, terdapat cukup waktu untuk peserta didik 
merefleksikan materi yang telah dipelajari, merupakan pembelajaran yang bermakna dan kontekstual (Muhammad, A, 2017; Saparina dkk, 2018; Ferry, et al, 2019).

Pada saat proses pembelajaran berlangsung siswa dilatih untuk dapat mengaplikasikan konsep, menggunakan keterampilan proses, kreativitas, dan sikap menghargai teknologi serta bertanggung jawab atas masalah yang muncul dilingkungan sehingga peserta didik mampu mencetuskan banyak gagasan, memunculkan cara atau saran, dan bekerja cepat. Model pembelajaran Sains Teknologi Masyarakat menuntut peserta didik untuk aktif memecahkan masalah yang kaitannya dengan dunia nyata, mengkosntruk pengetahuannya sendiri serta menggali potensi yang ada dalam diri peserta didik, peran dan tugas guru dalam hal ini adalah membimbing dan memberikan umpan balik pada saat proses pembelajaran berlangsung, hal ini sejalan dengan pemikiran Yanto Budhi Raharjo, perkembangan optimal dari kemampuan berpikir kreatif peserta didik dalam lingkungan pembelajaran berhubungan erat dengan cara guru mengajar. Pola pembelajaran dan interaksi yang lebih memberikan kepercayaan, dorongan serta motivasi terhadap peserta didik akan menciptakan gagasan-gagasan baru (Aunurrahman, 2017).

Data hasil angket self regulation pada kelas eksperimen menunjukkan perbedaan yang signifikan dengan kelas kontrol, hal ini dapat terjadi karena model sains teknologi masyarakat tidak hanya berorientasi pada penguasaan konsep saja tetapi sikap yang akan mempengaruhi konstruksi konsepkonsep yang baru sehingga dapat memecahkan masalah dunia nyata dengan pengaturan diri dan sadar akan pemikiran sendiri (Eva, L, 2018). Keterkaitan antara teknologi dan sains adalah usaha mengubah ilmu pengetahuan yang semulaabstrak menjadi nyata, agar konsep - konsep yang diperoleh peserta didik tidak mudah hilang. Hubungan antara model pembelajaran Sains Teknologi Masyarakat terhadap kemampuan berpikir kreatif dan self regulation terletak pada keunggulan model ini mampu menjadikan peserta didik berpikir rasional, dan mengkosntruk pengetahuan yang sadar atas pemikirannya sendiri, sehingga peserta didik mengganggap permasalahan adalah tantangan baru yang harus dipecahkan. Model pembelajaran Sains Teknologi Masyarakat ini juga tidak terpakupada kepentingan aspek kognitifnya saja, namun juga afektifnya yang dalam hal ini adalah self regulation, model ini mampu mengembangkan potensi otak dengan maksimal, ranah sikap yang meliputi sikap positif yang ditunjukkan pada saat proses pembelajaran, dan ranah aplikasi yaitu peserta didik mampu memberikan contoh dan konsep ilmiah dalam kehidupannya.

\section{KESIMPULAN}

Adapun kesimpulan dalam penelitian ini adalah terdapat pengaruh model sains teknologi masyarakat terhadap kemampuan berpikir kreatif dan self regulation pada peserta didik kelas VIII SMPN 1 Sumberejo.

\section{DAFTAR RUJUKAN}

Anna, P. (2007). Sains Teknologi Masyarakat. Bandung : PT Remaja Rosdakarya. 
Aunurrahman. (2017). Belajar dan Pembelajaran. Bandung : Alvabeta.

Ayu, M. A., Ketut, A \& Ketut, A.P. (2017). Pengaruh Pendekatan Sainstifik Berbantu Model STM Terhadap Kompetensi Pengetahuan Ipa Siswa Kelas V. Jurnal Pendidikan Guru Sekolah Dasa., Vol. 1 No.2.

Budhi, Y. (2016). Pengaruh Model STM Terhadap Keterampilan Berfikir Kreatif Dan Sikap Ilmiah Siswa. Jurnal Pendidikan. Volume 3 Nomor 1.

Darmiyati, Z.(2010). Humanisasi Pendidikan . Jakarta: Bumi Aksara.

Dedi, S. (2019). Kreativitas, Kebudayaan, Dan Perkembangan IPTEK. Bandung : ALFABETA.

Eva, L. (2018). Strategi Self Regulated Learning dan Prestasi Belajar Kajian Meta Analisis Jurnal Psikologi Universitas Islam Negri Sunan Kalijaga Vol.3,No.I.

Ferry, D., Jepriadi, \& Kamil, D. (2019). Peningkatan Hasil Belajar Biologi Siswa Melalui Penerapan Media Video Animasi Tiga Dimensi (3D). Pedagogi Hayati, 3(2), 1-11. doi:10.31629/ph.v3i2.1641

Frangkel, R \& Wallen, E.N.(2017). How to Design and Evaluate Reseach in Education.Edition 6. New York : The Mc Graw Hill Companies.

Hasanah, E. (2019). Pengaruh Penggunaan Media Pembelajaran Terhadap Peningkatan Berfikir Kreatif Peserta Didik. Jurnal Teknologi Pendidikan Pembelajaran. Volume 4 Nomor 1.

Martono, N.(2015) Metode Penelitian Kuantitatif Analisis isi dan Analisis Data Sekunder.Jakarta : PT RajaGrafindo Persada.

Muhammad, A. (2017) Psikologi Remaja Perkembangan Peserta Didik . Jakarta: Bumi Aksara.

N.W. Heni, D. (2017). Pengembangan Perangkat Pembelajaran IPA Dengan Setting Sains Teknoogi Masyarakat Untuk Meningkatkan Keterampilan Proses Sains Dan Keterampilan Berpikir Kreatif Siswa SMP, Jurnal Program Pasca Sarjana Universitas Pendidikan, Vol 5, No. 2. H, 10

Nugroho R. \& Aripin (2018). HOTS Kemampuan Berpikir Tingkat Tinggi : Konsep, pembelajaran, dan soal-soal. Jakarta : PT Gramedia Widiasarana Indonesia.

Purwakarti, E. (2016). Pengaruh Model Collaborative Learning Terhadap Kemampuan Pemecahan Masalah Matematika Dan Self Regulation Kelas V SD .Jurnal Penelitian Ilmu Pendidikan. Volume 8 Nomor 1. .H.109

Rina, P. U., Riezky, M. P, \& Umi, F.,(2017). Pengaruh Model Pemebelajaran PBL Berbantu Instagram Terhadap Kemampuan Berfikir Kreatif Siswa Kelas X SMA Negeri 8 Surakarta, Jurnal Pendidikana Biologi, Vol 4, No.1.

Saparina, R, Slamet, S, \& Maridi. (2018). pengaruh model STM terdahap belajar biologi siswa kelas X SMA N colomadu. Jurnal bio.pendagogi.vol,4. No. 4. H.61

Smarabawa. (2019). Pengaruh Model Pembelajaran Sains Teknologi Masyarakat Terhadap Pemahaman Konsep Biologi Dan Keterampilan Berpikir Kreatif Siswa SMA, Jurnal Program Pascasarjana Universitas Pendidikan Ganesha Program Studi IPA, Vol.3, No.1, H. 19

Sugiono. (2017). Metode Penelitian Pendidikan Pendekatan Kuantitatif, Kualitatif, dan R\&D. Bandung: Alfabeta.

Sastria, E., Susanti, T., Novallyan, D., \& Alfatwa, P. A. (2020). Persepsi Mahasiswa Terhadap Praktikum Biologi Umum Jurusan Tadris Biologi Fakultas Tarbiyah Dan Ilmu Keguruan 
IAIN Kerinci. Symbiotic: Journal of Biological Education and Science, 1(1), 42 - 52. https://doi.org/10.32939/symbiotic.v1i1.3

Tatang, Y. E. S. (2016) Identifikasi Proses Berpikir Kreatif Siswa dalam Pengajuan Masalah (Problem Posing) Matematika Berpandu dengan Model Wallas dan Creative Problem Solving (CPS)", Jurnal, vol.1,no.3.

Widodo, A., Wuryastuti, S., \& Margareta. (2007). Pendidikan IPA di SD. Bandung: UPI PRESS. 